\title{
Women "Cronistas" in Colonial Latin America
}

\author{
VALERIA A ÑÓN \\ Translation by WENDY GOSSELIN
}

\section{Archive Images}

Mexico, 1537. Alone in her jail cell, María de Bárcena reflects on the accusations against her, weighs the testimonies, and speculates on her destiny. Accused of witchcraft, a crime penalized under the Inquisition, she will have opportunities to present her version of the events or to bring forth witnesses that will be limited. De Bárcena has heard rumors that Villafaña's wife, a member of one of Mexico's richest families, is involved in one of the testimonies. The jailed woman knows that her silence will prove as important as her voice, which will be subject to intercession by the notary's quill and to the argumentative framework imposed by the inquisitorial interrogation. Her destiny, then, depends on the fragile balance between speaking and remaining silent and on her shrewd ability to negotiate the norms of ecclesiastical power and social condemnation.

Asunción, Paraguay, 1556. Isabel de Guevara writes to Governess Princess Doña Juana in a highly uncommon analepsis describing the discovery and conquest of Río de la Plata, while highlighting the critical role women have played in supporting the conquistador. In the short but fundamental dialogue that is established with the governess, criticism, remembrance, and a written silence intermingle, configuring a textual locus for her authorship that creates a sphere of sisterhood through her plea to the governor.

Spain, 1598. Francisca Pizarro, daughter of the Inca queen, Inés Huaylas, and the conquistador Francisco Pizarro, has fallen ill. She dictates her last will and testament, a critical document not only because it will be used to distribute her assets, but also because it allows her to establish authority through her voice, construct an image for herself after her passing, and attest to her Catholic faith. The will gives her a chance to demonstrate her attachment to Spanish culture, an attachment that can be seen in both her education and her extended stay in Spain. 
These archive images bring forth myriad questions about how the past and present are represented. They show the violent intersection of world visions and discursive traditions; translation and survival; dialogue, destruction, and change. It is a storytelling that is individual as well as collective and a space for that which has been expelled or relegated from hegemonic discourse, although this recognition may be limited to a specific period, stuck in the quagmire of incessant change.

The most critical question that arises here is the following: To whom are we referring when we speak of women cronistas in colonial Latin America? Which types of writing and texts are we indicating? If these texts can be grouped under the broad concept of colonial chronicles, what connections can be made with the predominant colonial literary corpus - a literature directly associated with masculine voices, articulated from the sphere of power and authority? What bonds are established with the actors (soldiers, monks, indigenous nobles, mestizos)? As Julie Greer Johnson has noted, "Because men dominated the writing of both history and literature, the image of women during the colonial period is largely based upon their vision" (I57). Nevertheless, Greer Johnson chooses to focus on men's representation of women. In contrast, this chapter reveals how women represent, write, speak, remember, and affirm themselves and make requests in the complex sphere of the early Latin American colonial world.

We should also consider the debate on the suitability of notions such as "literature," "culture," and "text" that began in the I980s (especially in texts by Mignolo, Adorno, Castro Klarén, Klor de Alva, and many others). The question of suitability becomes even more necessary when rethinking the colonial corpus from the perspective of female cronistas. This chapter provides an overview of women cronistas in addition to some biographical information and proposes using the figure of the female cronista to reconsider other discursive forms and other traditions in which the importance of orality and family (in terms of narration and social bonds) takes center stage. The analysis of the legal-inquisitorial discourse (cases against María de Bárcena, María de Contreras, and even against those who aided Isabel Moctezuma) will be highlighted. Another focal point will be the rhetoric of the legal-notarial discourse, which can be found in reports, ordinances, petitions, and probanzas (Isabel de Guevara and Isabel Barreto, among others). I will also refer to letter writing, a crucial discursive form with regard to women's writing; this includes letters drafted for both the public sphere (the famous missive from Isabel de Guevara to Princess Juana) as well as the family sphere (numerous letters from emigrants of the Indies). 
The chapter is organized around different subject positions, positions configured around what I refer to as diverse rhetorics: a rhetoric of silence/ silencing, a rhetoric of request and claim, and a rhetoric of deviation. The aim, then, is to review the literary corpus within a framework where criticism and the compilation of sources are fragmentary and dispersed. This is an important pending task in Latin American literary studies.

\section{Cartographies of Silence}

From the very beginning, the conquest of the Americas was a controversial enterprise. Interests, disputes, illegitimacies, rebellions, and persecutions revealed the tension between the known and the new, the legitimate and the illegitimate, legality and its fringes. This historic event was accompanied by a copious volume of written texts required for the governance of the Spanish empire. Tension and controversy frame this textual universe where expert knowledge is juxtaposed with the experience of the witness-actor to form the core of the dispute. To a certain extent, this was a process by which new protocols for authorizing historical discourse came to light. But nevertheless, the voices are overwhelmingly masculine. This can be said of those who actually did the writing, as well as of the illiterate majority who found a voice, choosing from among a broad selection of legal discourses, particularly probanzas and petitions.

Therefore, in accordance with the mechanism of the conquest, for centuries Western voices configured a tale of the Americas that evidenced an intense desire for a utopian space that never existed. These masculine voices rested on the author's name to endorse the truth of what had been said, either founded on experience springing from his historical humanistic knowledge or through his legal rhetoric. Thus, plenty is known (or has been said) of conquistadors, monks, historians, and travelers. Very little is known about the women who accompanied these men, that is, the women who experienced and suffered the conquest. These women include both Spaniards abroad (their presence is documented from Columbus's second journey), as well as indigenous women (both noblewomen and commoners), all of whom were affected by the violent experience of the conquest. In the case of the indigenous women, they were often pawns or gifts offered by indigenous leaders to Spanish captains or soldiers, though many were agents of their own destiny in spite of the misfortune - the case of Malinche-Doña Marina is emblematic in this regard.

It is true that "illiteracy impeded the vast majority of the New World's females from documenting their daily lives and from recording personal 
feelings and responses to the quality of their existence" (Greer Johnson 157). It is also a fact that women's presence has been overlooked by historians and by literary scholars for centuries, and this oversight has only begun to be addressed in the past few decades. Reorganizing the Latin American literary corpus involves not only replacing proper names, writings, and experiences, but also thinking about them in terms of predominant rhetorics that grant these voices a framework and future, even beyond the biographical vicissitudes. Let us thus examine a brief map of authors and texts, while delving into the rhetorical dimension.

In general terms, the predominant genres in the writing/voice of these women cronistas are letters, inquisitorial transcripts, and will and testaments, all of which were directly connected to the legal-notary discourse.

Letters: The first European images of the "New World" are configured through the rhetoric of letters, specifically letters sent to authorities. Two of the earliest and most renowned examples are the letter from Columbus to Luis de Santángel and the Catholic king and queen (I492) and the letters from Hernán Cortés to Charles V (1519-I526). Medieval tradition allowed any vassal to write directly to an authority and thus encouraged letter writing; however, the letter had to follow strict rules of captatio benevolentiae and use the descriptive-argumentative discourse required of a report to the authorities. Soon the nobility of the surviving indigenous populations adopted this format to send their requests, as can be seen in the Descripción de la cibdad y provincia de Tlaxcala (1572) by Diego Muñoz Camargo and the Nueva Corónica y Buen Gobierno (I6I3-1615) by Felipe Guamán Poma de Ayala, among others. In addition to these letters addressed to an authority and to a broader public, there were innumerable letters from soldiers, travelers, monks, and even adventurers who had gone to the Americas seeking fortune, a goal few actually achieved. The rhetoric of these missives is usually built on a pious depiction of oneself followed by requests, usually for news, goods, and the possibility of family members being sent to the new land.

The letters written by women are part of this extensive corpus, and they pass through both the public and private spheres, though the latter usually prevails. This is because in the tradition of letter writing, women's writing is relegated to personal or family affairs (Marrero Fente I3). However, there are several letters directed to the authorities, the most famous of which is that sent by Isabel de Guevara to Governess Princess Juana, written in Asunción in 1556 and currently stored at the National Historic Archive in Madrid. De Guevara, in fact, has been characterized as the "first Rio de la Plata feminist" because her letter narrates the conquest of Rio de la Plata while highlighting 
the role of women (Lopreto 43). Without them, the letter states, the conquest never would have been possible: "Your Majesty will believe that without their graciousness, men would have been finished" (Scott I5). In an articulation that fluctuates between testimony and legal discourse, her protest against the scarce recognition of women's achievement echoes one already made by low-ranking soldiers on expeditions to Mexico, Peru, and the Amazons, though de Guevara gives her protest a new twist. What is significant, but not unique, about her brief letter is, first, that it is written by a woman, and, second, its royal addressee, that "very high and very powerful ... Princess Governess Doña Juana," daughter of Charles V and Queen Isabel, and at that time governess of Castilla and of the Kingdoms Abroad (Quispe Agnoli 83; Scott I5). A kind of feminine camaraderie is created, one based on identification among women and one that evokes a certain contempt for the norms that relegate women's writing to the personal realm, thus embarking upon a path that many other women would later follow.

Thus, the experience of the Americas creates new possibilities for enunciation for the controversial voices of the subaltern, voices that speak out to challenge a notion of truth that rests on the "visto y vivido" [seen and lived], as in the paradigmatic case of Bernal Díaz del Castillo. However, this experience also expands the places for speech and creates closer ties to the authorities ("Sujetos dicentes," Mignolo 9). For this reason, there were countless letters from women to the king and the Council of the Indies during the sixteenth century, though few have been published. In any case, articulated from legal-testimonial discourse, they are constructed around a request, appealing to a certainty of their rights as female conquistadors or as the wives of conquistadors. These women provide a unique point of view on the experience of the "New World."

In the tales of perpetually burdensome daily life, the demand for a dialogue that was often cut short by time and distance, the disappointment and nostalgia that color the letters from emigrants to the Indies establish a written space for the female voice and an inter nos that reveals the flip side of the experience of conquest and colonization. Texts forgotten during centuries, these letters acquired visibility thanks to the work of Raúl Porras Barrenechea, Enrique Otte, and, more recently, Marta Fernández Alcaide and Yamile Silva. Written more from an ars dictaminis than from an ars epistolandi, they combine the pragmatism of the letter writing tradition with its time-deferred and distanced dialogues (Silva 92; Barrenechea 53). This is a communication gesture that is simultaneously a writing gesture, one even more powerful if we remember that women were latecomers to the written word 
and recall that mediators (scribes, notaries public) were frequently required (Bouvet 25). Although these letters share some of the features of the general corpus, such as the weight of the deixis, the "updating of the family history and [reminder] of the obligations that blood ties require" ... and a "double sense of belonging stretched between the past and the present," they also have particular inflections that give shape to a writing unique to women (Altuna 34). Often addressed to other women, and to distant or silent men as well, these letters configure a feminine space that opens the door to complaints: "Dear and beloved brother of my heart: Many letters have I written to you without receiving a reply," María de Carranza, Puebla, I589; "Dear sister: Many a letter have I written to your grace, but have yet to receive your response, and I am stricken with horror, as your grace used to respond to each and every one," Ana de Espino, Panamá, 1583); and to requests for the other to come: "Dear Sister: In another letter I have written to your grace requesting that you send son-in-law and one of your daughters, the young one, as your grace knows I have no one to whom I may leave my worldly possessions" (Ana Macías, Puebla, 1575). These constants allow us to classify them as "letters to maintain contact with relatives and letters to family members requesting assistance," according to García Moutton, and as letters that outline a rhetoric of emotivism and grievance (32I).

In their performative dimension, the salutatio and exordio are brief, while the narratio and the petitio become particularly significant. The conciseness that characterizes these letters results from a certain discomfort with the rules of written text; they reveal an empty space and take a detour that gives way to new subjectivities:

Writing reveals the problematic relation between the desires of women authors to represent themselves through a language that does not belong to them, one in which they do not feel reflected. This lack of recognition is the result of an androcentric tradition of discourse that is both exclusive and excluding, a discourse in which women have participated exclusively as objects. (Silva 92)

Will and testaments have a long tradition in the West, particularly among women, since they offer a chance for articulating one's own voice in a higher discursive tradition; they allow for a reflection on the proximity of death and constitute a privileged textual space for self-configuration. In colonial times, women such as Isabel Moctezuma (Mexico, I509?-1550), Francisca Pizarro (Cuzco, I534-Madrid, I598), and María Díaz Rivadeneyra (¿Galicia?-Havana, Cuba, 1644) were among those who left a noteworthy will and testament. 
Tecuipochtzin, or Isabel Moctezuma, the firstborn daughter to Motecuhzoma II and Miahuazóchitl, was married at the age of eleven to her uncle Cuitláhuac, who died a short time later. She then married Cuauhtémoc and was imprisoned by the Spaniards with the fall of Tenochtitlan in I52I. Her husband was murdered during the trip to Las Hibueras in I524. When Hernán Cortés returned to the city and Isabel learned of her husband's death, the Spanish captain granted her "the income and revenues of the town of Tacuba and its surrounding villages" in I526 (Cortés 380). It was the largest indigenous encomienda of the Mexican Valley, though it was meager in comparison to what the princess would have received as a direct heir to the uey tlatoani. Later Cortés moved Isabel to a house where his other concubines lived. There she became pregnant with the child of the Extremaduran captain and gave birth to a daughter, Leonor Cortés Moctezuma, who was taken from her and handed over to Juan Altamirano, a political ally of Cortés. She never saw her daughter again. Married to different husbands, she gave birth to six more children. In 1550 Isabel drafted her will with the consent of her husband, Juan Cano. Although the voices of her husband and her guardians interpolate her voice, the will and testament reveals the authority of this complex woman. First, she dedicates a significant portion of the text to constructing an image of herself as closely associated with the Catholic faith, her keeping with the precepts of the church, and her involvement in charity and mass. She also uses the document to distribute her numerous assets selectively between her children and husband while avoiding any reference to her firstborn, Leonor, the daughter of the conquistador (Pérez Rocha).

There are both similarities and differences when comparing Moctezuma's life with that of Francisca Pizarro. Pizarro was born to Quispesisa (the sister of Atahualpa, later baptized Inés Huaylas) and Francisco Pizarro. Atahualpa himself handed over his sister to Pizarro, perhaps to gain good favor with the conquistador. Francisca and her brother, Gonzalo Pizarro, were both separated from their mother at a very young age as the result of new political alliances and arrangements, and later she was exiled in Spain, where she lived for more than forty years until her death in I598. In Spain, she married her uncle, Hernando Pizarro, and spent a decade locked up in Castillo de la Mota with him, bearing five children. Three years after becoming a widow she married a much younger man, Pedro Arias Dávila Portocarrero, the eldest son of the conde de Puñoenrostro. Until her death, she lived in Madrid with her new husband, squandering most of her fortune. Her will and testament emphasizes her Spanish acculturation while ignoring her Inca roots (Pizarro 97). She emphasizes her Catholic faith and her belonging to the Spanish universe and 
culture, projecting an image of herself as the beloved daughter of the conquistador Francisco Pizarro.

Moving on to the seventeenth century, a time during which the colonial administration was being consolidated, the Spaniard María Díaz de Rivadeneyra accompanied her husband to the Caribbean, where they would become very rich. Díaz de Rivadeneyra provides a good example of the path of those "Spanish women across the sea" (Maura 23). There were few women in the New World during the first years of the conquest; later imperial decrees exhorted them to make the journey (López de Mariscal 73). The women who did cross the Atlantic were able to carve out a certain space of autonomy and power in the incipient colonial societies - initially through marriage and later during widowhood. In the case of Díaz de Rivadeneyra’s will and testament, the rhetoric of the Catholic faith and the emphasis on mass and charity work play a central role, thus forming an image of a pious woman. A notary public's voice mediates her own, attesting to the fact that "she appeared to be in her right mind but did not sign her name because she claimed to not know how" (Campuzano and Vallejo 87). However, in spite of the notary public's mediation, this woman's clear intention can be seen. Her will and testament is interesting not only in the way she divides her assets and money among her children and in-laws, but also in the way she stakes claim to standing debts, not to mention her intentions with regard to her "old" slaves, Maria and Pedro, whom she grants freedom upon her death. However, to her granddaughter Leonarda she leaves a "four-year-old black girl whom I own, a native to this city, born and bred in my household, whose name is Mariana" (Campuzano and Vallejo 84). This document thus reveals the complex workings of colonial power and the distances between women of different classes. This will and testament shows how these powerful women subscribed to an economic and social system that rested on slave labor: While Díaz de Rivadeneyra attempts to show generosity by giving her old slaves their freedom, her lack of reverence is revealed in her intentions regarding the young Mariana.

These three cases offer a metonymic sampling of the diverse social roles and loci of enunciation for the female voice, leaving a record of their willpower and decision, while revealing the complex interstices of colonial society.

Inquisitorial processes: Another inflection of female voices in the colonial discourse is found in the more prescriptive and punitive sphere of legal discourse. This voice can be seen in numerous inquisitorial processes against a variety of women, the majority of whom were accused of witchcraft.

In his analysis of Menocchio, the famous miller from Friuli, Carlo Ginzburg revealed that the inquisitorial sphere could be a privileged space for recovering 
subaltern voices. In keeping with this path, I propose to identify other dimensions of the feminine voice that must be read at the interstices of the questions of the inquisitor, the accusations of the witnesses, and the gravity of the Catholic Church. ${ }^{\mathrm{I}}$ Before the Holy Office, these women appeared as accusers, as witnesses for the prosecution and for the defense, and as defendants. The numerous transcriptions of trials, compiled by Chuchiak and by Campuzano and Vallejo, among others, present these voices as translated and transformed from the oral interrogation to the written summary of the inquisitor. The speaking of these women was organized in a rhetoric of silence and deviance, in an attempt to maneuver through all the possibilities for one's defense while avoiding any attempt by the inquisitor to trick them into affirming their guilt or appearing evasive. Three infamous trials are those of María de Sotomayor for polygamy (I538), of María de Armenta for witchcraft and sorcery (I536), and of María de Bárcena for sorcery and sexual magic (I537). These three cases offer a metonymic example of the workings of the Inquisition with regard to women and to the principal motives for such trials: cases of bigamy or polygamy and accusations of sorcery used to obtain sexual favors or to cause some kind of "damage" to their husbands (Lavrin 1978). In other words, control over women depended upon sexual morality and the institution of marriage with the church positioning itself as the governing entity. ${ }^{2}$

Accused of polygamy, María de Sotomayor was brought to trial in Mexico City between 1538 and I540. Married to a Spaniard in Toledo, Juan Castro, she married another Spaniard, Gaspar de Hurtado, in the New World. After hearing the testimonies of four witnesses for the prosecution (one of whom was a woman), and even testimony from her second husband, María de Sotomayor spoke in her own defense. De Sotomayor claimed that she had been notified of the death of her first husband in Spain before marrying for a second time. The sentence, which included an act of public humiliation, ordered de Sotomayor to be sent back to Spain to live with her first husband, which the defendant openly refused to do in a letter sent to the inquisitor in I538. In I540, she was arrested again, since she had traveled not to Spain but to the Viceroyalty of Peru in order to avoid exile from the New World and a gloomy future alongside her first husband. As she notes in her letter from I538: "I am afraid that if I was to return to Spain now I will lose my wealth and my health and any other number of dangers or inconveniences could occur" (quoted in Chuchiak 5762). María de Sotomayor faced oppressive inquisitorial power, revealing the possibilities of eluding (albeit temporarily) the sentences of the tribunal, in the framework of a social organization in which marriage could prove to be the worst punishment of all. ${ }^{3}$ 
Another common dimension in these processes against women is the accusations of "sorcery and witchcraft." Women of all social classes were accused of this, although it is known that the Holy Office was particularly considerate with upper class women and did not sentence them to acts of public humiliation even when they were found guilty. In any case,

the fact that women from all castas and social classes resorted to the use of superstition, often the only outlet at their disposal to better their lives, may also be a consequence of women's limited access to power in colonial Mexico. (Chuchiak 7256)

Here I will focus on two cases that reveal the different inflections of the female voice, social class and the use of confession and/or silence.

María de Armenta (a native of the Canary Islands who moved to New Spain) was reported for blasphemous acts to the Holy Office in Mexico City in 1536. The accusations were made by another woman, Ana Pérez, and included acts of witchcraft, heresy, and "sinful" sexual acts. The accusations sketch an image of a carefree, bold woman without fear of God, an image that is juxtaposed against the "pious" image that the accuser configures of herself. Nothing could be further from sisterly camaraderie; the inquisitorial institution apparently provided the perfect tool for staging rivalry and aversion. Guided by the inquisitor's questions during her "confession," María denies the most serious charges, though she names a mulatto and several Indian women in practices of witchcraft. Her words, which are turned against her by the inquisitor, construct an image of women connected with the occult, with sexuality, and with the manipulation of men. Condemned to acts of public humiliation and ordered to learn the Our Father and the Hail Mary, she was taken before the tribunal yet again in 1537 for not reporting to the office as ordered. As in the previous case, what is interesting here is that de Armenta's case reveals the possibilities for digression, the "tricks of the weak," to borrow Josefina Ludmer's term, to elude a court sentence (86). However, the "strategy of the strong" prevailed over the "tactics of the weak" sooner rather than later, since María de Armenta was ultimately sentenced to "perpetual exile and banishment from this Kingdom of New Spain” (De Certeau 29; Chuchiak 7278).

The case of María de Bárcena (Mexico City, I537) has several aspects in common with that of de Armenta, since they had similar backgrounds and were both were accused of witchcraft in cases involving comparable witnesses. However, de Bárcena's statements during her trial represent a point of inflection associated with the organization of social power in the complex colonial setting of New Spain. While the defendant initially denies the accusations of 
superstitious practices, her testimony changes when Villafaña's wife is mentioned. According to the testimonies, she had helped Villafaña through the intervention of a black woman named Marta. The Villafañas were one of the most powerful families in the city, and mentioning the wife's name in a trial of this sort would doubtlessly do the defendant more harm than good. As a result, de Bárcena remained silent, accepting the accusations and waiving her right to present witnesses in her defense. This meaningful silence reveals the marked distance between the lower classes and the dominant sectors and demonstrates her full awareness of her subaltern disadvantage. The differential treatment (which was also applied to noble indigenous women such as Isabel Moctezuma) determined one's possibilities to speak and one's need to remain silent, unveiling the heterogeneity of what is called "the feminine voice" when it is articulated with social and racial factors.

\section{Rhetorics and Poetics}

Beyond the biographical inflections and the questions of text genre, the written productions of these women cronistas can be characterized by certain rhetorics that together establish a specific poetics of the feminine voice that I will refer to as "poetics of presence-absence." Within the rhetorics utilized, the discursive genres intermingle with the objective of ensuring that one's own voice circulates. The corpus of colonial women's writing thus reveals strategies similar to the ones used by subaltern masculine voices (soldiers, Ladino translators, indigenous nobles), while taking advantage of every gap within the law of what can be said, in the words of Foucault: the direct dialogue with the authorities through letters, testimonies, probanzas, and will and testaments. However, these women cronistas, who write in a sphere, both of genre and language, that is not their own, shine light on new forms of subjectivity; therein lies the radical novelty of these texts.

I will refer first to the rhetoric of deviation, a characteristic of all the texts produced by female cronistas, though the degree to which it is used varies. From our corpus, there are clear examples of this in the cases of Francisca Pizarro, María de Sotomayor, and María de Armenta, and even in certain sections of the letter from Isabel de Guevara. This rhetoric is founded on an enunciation locus different from what would be expected; it is a position that does not openly challenge the legality or language of the empire but instead attempts to shift away from it. Its principal figures are those of veiled controversy, such as argumentation through enumeration (of tasks and sufferings), reverse argumentation (with respect to those who refuse to acknowledge the 
fundamental role of women in the conquest or with regard to accusations made during inquisitorial proceedings), argumentation by analogy or causality (in the letter by Isabel de Guevara and the will and testaments of Isabel Moctezuma and María Díaz de Rivadeneyra). To this we can add the initiation of a dialogue of women with authorities (in public documents) and with relatives (in personal letters) that enables a bare syntax, an accentuated brevitas, a certain colloquialism. This gives way to speakers who make digressive use of the intricate rules of literary culture to construct a speech that struggles for a place of its own in the hidden space of the feminine voice.

As a complement to the rhetoric of deviation, there is the rhetoric of request and claim (Isabel Moctezuma, Isabel de Guevara, personal letters) that is articulated around the textual configuration of an accentuated pathos associated with testimony. These are women who suffered the weary journey of the conquest, colonization, and even the loss of children (a dimension that is ever-present in the workings of feminine memory). It is spoken from the position of a subject who relies on the services provided by parents, husbands, and close relatives, but one who also makes requests based on her own experience and heritage. The captatio benevolentiae and the hyperbole characteristic of salutatios and exordios are utilized to construct images of pious women, through a religiousness that makes any petitio legitimate. As for the synthesis and ellipsis that articulate narratio and petitio, they disclose the economic and symbolic demands that are at the core of these writings.

Last, the rhetoric of silence presents a somewhat blurry first person, one diluted by the hyperbole of an accentuated captatio benevolentiae that usually finds expression in the legal-inquisitorial discourse. The predominant figures of this discourse are the ellipsis, which can be seen in both silence and one's renouncing of certain rights (María de Bárcena), and the denial of accusations and of a past from which one wishes to escape, a failed marriage in the case of María de Sotomayor; and indigenous culture and one's native tongue in the case of Francisca Pizarro. This rhetoric thus prevails in the inquisitorial sphere, but it also extends beyond this sphere; a will and testament can also create a space for silence about one's own past. This is especially the case in contrast with what is affirmed: dedicated religiousness, one's belonging to the culture of the conquistador, and the absence of any idolatry or heresy. Thus, a subject's denial of her own being appears as an extreme tactic of survival in the colonial society of the sixteenth century.

Finally, I would like to include one additional and radical example of silence / silencing: the reference to certain women who are spoken of only in passing in the crónicas, though never with a voice of their own: Doña Leonor Cortés 
Moctezuma, never acknowledged by her mother, Isabel Moctezuma; Doña Luisa Xicoténcatl or María de Estrada (the first a noble Tlaxcaltecan woman; the second, a Spanish woman to be reckoned with). These are women who experienced the violence firsthand, the horror of the "Noche Triste" [Sad Night] when the people fled from Tenochtitlan and later, the memory of what was. We must refer to the most famous female character, Doña Marina-Malinche, mentioned only in passing by Cortés and recreated through Western traditions by Bernal Díaz del Castillo and Francisco López de Gómara, also anathematized or made into a figure of worship by indigenous codices and chronicles (Añón II8; Brotherston I8). These are perfect examples of "covering up the other," in the words of Dussel, a process even more ominous in feminine voices and figures, victims of the many layers of silencing.

These dimensions configure the poetics of presence-absence that defines the writing of these women cronistas. This poetics is organized around the appropriation of discursive traditions and other languages and clearly oscillates between tradition and rupture in terms of the roles assigned to the female subject during the experience of conquest and colonization. If ellipsis and digression are the predominant tactics that ensure the legibility and circulation of these texts, the affirmation of one's own worth is also a central part of these enterprises. Letters and will and testaments contribute to the self-figuration of the woman as a subject with willpower and decision, far from the passivity that was required of her. This writing is about creating a new social space, one constructed by these women cronistas with their bodies and their words.

\section{Notes}

I In New Spain, the Holy Office was established at the Episcopal Palace in 1536 by Bishop Juan de Zumárraga (Alberro Solange). From its beginnings, numerous trials were held against the indigenous; the most resounding was the trial and sentencing of the chief of Tezcoco, Carlos Ometochzin, in I539. In I569, Phillip II officially created the Tribunal of the Inquisition in New Spain and in 1579 "[he] removed the indigenous peoples from the tribunal of México's jurisdiction, which covered all of New Spain, including the Philippines, Guatemala, and the bishopric of Nicaragua" (Chuchiak 359). In the Viceroyalty of Peru, the tribunal was founded during the administration of Viceroy Toledo in 1570 . Over the course of the seventeenth century, 64 of the I84 defendants brought to trial at the tribunal were women, and most of these women were tried for witchery (Mannarelli).

2 In fact, "the crime of bigamy appears to have been more actively prosecuted in New Spain than in the Peninsular tribunals... Of 219 bigamy cases prosecuted in New Spain during this time period [ $157 \mathrm{I}$ to 1700 ], only 24 cases pertain to women, and only 7 of those cases included white Spanish women” (Chuchiak 560I). 
3 Naturally, the second sentence was even more severe, since besides being stripped of her assets, she was ordered to be taken "in chains and irons to the port of Veracruz and that there she should be forcibly placed upon one of the ships that waits there" (Chuchiak 5782) or otherwise face the death penalty.

\section{Works Cited}

Alberro, Solange. Inquisición y sociedad en Nueva España en México 1571-1700. México: FCE, I988.

Altuna, Elena. "Imágenes del Perú en las cartas de los inmigrantes." Retórica del desagravio. Salta: Cepiha, 2009. 33-44.

Añón, Valeria. La palabra despierta: Tramas de la identidad y usos del pasado en crónicas de la conquista de México. Buenos Aires: Corregidor, 2012.

Barrenechea, Ana María. "La epístola y su naturaleza genérica." Dispositio XV.39 (1990): $5 \mathrm{I}-65$.

Bouvet, Nora. La escritura epistolar. Buenos Aires: Eudeba, 2006.

Brotherston, Gordon. "La Malintzin de los códices." La Malinche, sus padres y sus hijos. Ed. Margo Glantz. México: Taurus, 20II. 17-38.

Campuzano, Luisa y Catharina Vallejo, eds. Yo con mi viveza: Textos de conquistadoras, monjas, brujas, poetas y otras mujeres de la colonia. La Habana: Casa de las Américas, 2003.

Cortés, Hernán. Documentos cortesianos I. Ed. José Luis Martínez. México: FCE, I994.

Chuchiak, John F. The Inquisition in New Spain, 1536-1820: A Documentary History. Baltimore: John Hopkins UP, 20I2. Kindle edition.

De Certeau, Michel. The Practice of Everyday Life. Trans. Stephen F. Rendall. Berkeley: California UP, 1984.

Dussel, Enrique. I492. El encubrimiento del otro. La Paz: UMSA, 1994.

Fernández Alcaide, Marta. Cartas de particulares de Indias del siglo XVI: Edición y estudio discursivo. Madrid-Frankfurt: Iberoamericana-Vervuert, 2009.

Foucault, Michel. Archaeology of Knowledge. Abingdon: Routledge, I989.

García Moutton, Pilar. "Las mujeres que escribieron cartas desde América." Anuario de lingüistica hispánica XII-XIII I (1996-1997): 319-326.

Ginzburg, Carlo. The Cheese and the Worms. Trans. John Tedeschi and Anne Tedeschi. John Hopkins UP, 1992.

Greer Johnson, Julie. Women in Colonial Spanish American Literature. Westport, CT: Greenwood Press, 1983.

Lavrin, Asunción. Ed. Latin American Women: Historical Perspectives. Westport, CT, and London: Greenwood Press, 1978

López de Mariscal, Blanca. "El viaje a la Nueva España entre I540 y I625: El trayecto femenino." Historia de las mujeres en América Latina. Eds. Juan Andreo and Sarah Beatriz Guardia. Perú-Murcia: CEMHAL-Universidad de Murcia, 2002. 73-88.

Lopreto, Gladys. "Isabel de Guevara: la primera feminista." Todo es historia 34 (199I): 43-49.

Ludmer, Josefina. "Tricks of the Weak." Feminist Perspectives on Sor Juana Inés de la Cruz. Ed. Stephanie Merrim. Detroit: Wayne State UP, 199r. 86-93.

Mannarelli, María Emma. Hechiceras, beatas y expósitas: Mujer y poder inquisitorial en Lima. Lima: Fondo Editorial del Congreso de Perú, 2000. 
Marrero Fente, Raúl. "De retórica y derechos: estrategias de reclamación en la carta de Isabel de Guevara." Hispania 79.I (I996): I-7.

Maura, Juan Francisco. Españolas de ultramar en la historia y la literatura. Valencia: Universidad de Valencia, 2005.

Mignolo, Walter. "Sujetos dicentes, roles sociales y formas de expresión." Revista de Crítica Literaria Latinoamericana XXI.4I (1995): 9-3I.

Otte, Enrique, ed. Cartas privadas de emigrantes a Indias, 1540-1616. México: FCE, I988.

Pérez Rocha, Emma. Privilegios en lucha: La información de doña Isabel Moctezuma. México: INAH, 1988.

Pizarro, Francisca. “Testamento.” Doña Francisca Pizarro. Ed. María Rostworowski. Lima: IEP, 2003. 96-I07.

Porras Barrenechea, Raúl. Cartas del Perú, 1524-1543. Lima: Sociedad de Bibliófilos Peruanos, 1959.

Quispe Agnoli, Rocío. "Discursos coloniales escritos y agencias femeninas: La 'Carta a la Princesa Juana' de Isabel de Guevara.”. Cuaderno internacional de estudios humanisticos $y$ literatura 5 (2005): 8I-9I.

Scott, Nina, ed. Madres del Verbo/Mothers of the Word: A Bilingual Anthology. U of New Mexico P, 2000.

Silva, Yamile. Prácticas escriturales femeninas: espacialidad e identidad en epistolas en la Colonia (Rio de la Plata, siglos XVI-XVII). Ph.d. Thesis. University of Massachusetts, 20II. 